\title{
Moral sensitivity components identified among nurses from Intensive Care Units
}

\author{
Componentes da sensibilidade moral identificados entre enfermeiros de Unidades de Terapia Intensiva \\ Componentes de la sensibilidad moral identificados entre enfermeros de Unidades de Cuidado Intensivo
}

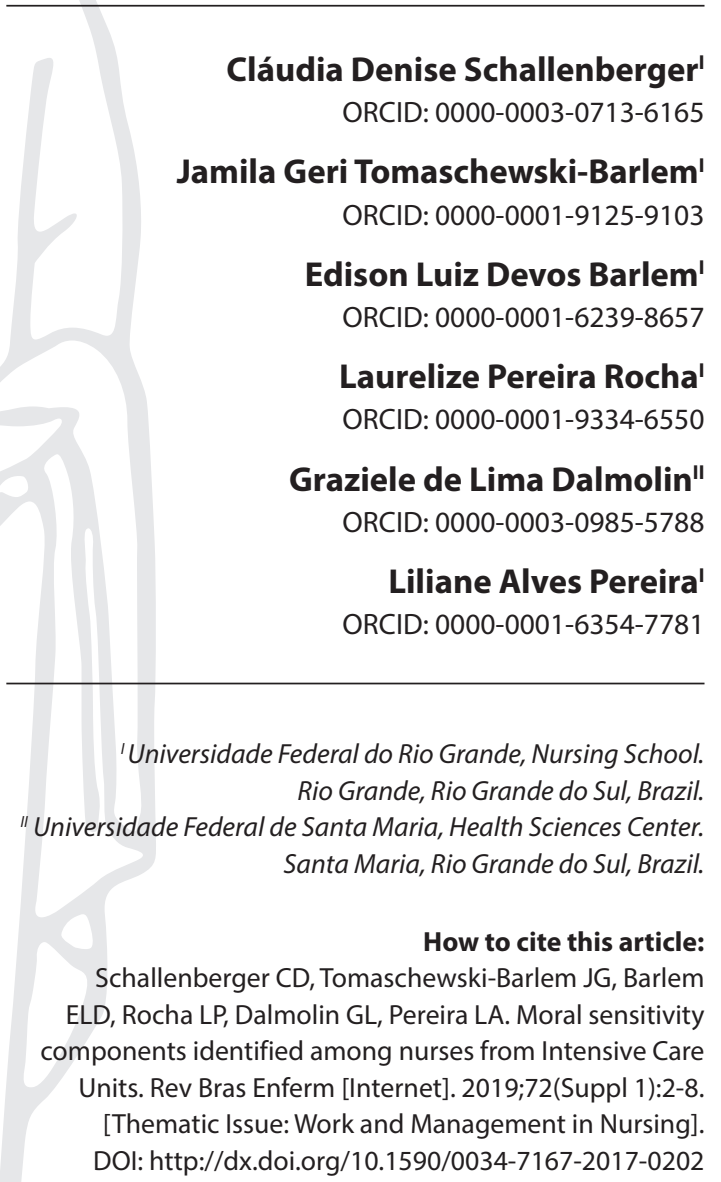

Corresponding Author:

Cláudia Denise Schallenberger

E-mail: deniseschal@yahoo.com.br

Submission: 04-10-2017

Approval: 10-01-2017

\begin{abstract}
Objective: to identify ethical problems from the components of moral sensitivity among nurses of Intensive Care Units. Method: qualitative, exploratory-descriptive study developed in a hospital in the South of Brazil with 19 nurses working in intensive care units through semi-structured interviews that were analyzed through discursive textual analysis. Results: ethical education, dialogue, relationships with other health team members, professional autonomy, knowledge, personal values, effective communication, leadership and patients' positive outcomes were identified as important components of nurses' moral sensitivity, and comprise the domains of moral consciousness, benevolent motivation, and spontaneous moral perception. Final considerations: the components of moral sensitivity identified in this study facilitate nurses' instrumentalization in the face of decision making and ethical problems in the intensive care setting.

Descriptors: Moral; Nursing; Ethics in Nursing; Critical Care; Health.
\end{abstract}

\section{RESUMO}

Objetivo: identificar, entre enfermeiros de Unidades de Terapia Intensiva, problemas éticos com base nos componentes da sensibilidade moral. Método: pesquisa qualitativa, do tipo exploratório-descritiva, desenvolvida em instituição hospitalar do Sul do Brasil, com 19 enfermeiros atuantes em unidades de terapia intensiva. Dados foram coletados por meio de entrevistas semiestruturadas e analisados mediante análise textual discursiva. Resultados: a educação ética, o diálogo, a relação com os demais membros da equipe de saúde, a autonomia profissional, o conhecimento, os valores pessoais, a comunicação efetiva, a liderança e os resultados positivos apresentados pelos pacientes constituem importantes componentes da sensibilidade moral dos enfermeiros, compreendendo os domínios da consciência moral, motivação benevolente e percepção moral espontânea. Considerações finais: os componentes da sensibilidade moral identificados neste estudo facilitam a instrumentalização dos enfermeiros diante das tomadas de decisões e de problemas éticos no ambiente de terapia intensiva.

Descritores: Moral; Enfermagem; Ética em Enfermagem; Cuidados Críticos; Saúde.

\section{RESUMEN}

Objetivo: identificar los problemas éticos a partir de los componentes de la sensibilidad moral entre enfermeros de Unidades de Cuidado Intensivo. Método: investigación cualitativa, del tipo exploratorio-descriptivo, desarrollada en institución hospitalaria del sur de Brasil con 19 enfermeros actuantes en unidades de cuidado intensivo, por medio de entrevistas semiestructuradas y analizadas mediante el análisis textual discursivo. Resultados: la educación ética, el diálogo, la relación con los demás miembros del equipo de salud, la autonomía profesional, el conocimiento, los valores personales, la comunicación efectiva, el liderazgo y los resultados positivos presentados por los pacientes fueron identificados como importantes componentes de la sensibilidad moral de los enfermeros, que comprende los dominios de la conciencia moral, motivación benévola y percepción moral espontánea. Consideraciones finales: los componentes de la sensibilidad moral identificados en este estudio facilitan la instrumentalización de los enfermeros delante de las tomas de decisión y los problemas éticos en el ambiente de cuidado intensivo.

Descriptores: Moral; Enfermería; Ética en Enfermería; Cuidados Críticos; Salud. 
Moral sensitivity components identified among nurses from Intensive Care Units Schallenberger CD, Tomaschewski-Barlem JG, Barlem ELD, Rocha LP, Dalmolin GL, Pereira LA

\section{INTRODUCTION}

In the course of nursing practices, situations that generate ethical problems are recurrent, and part of professional daily routine. Such situations lead nursing professionals to experience conflicting circumstances in their daily life, which involve the autonomy of the profession, work organization and conflicts arising from patient care, such as the use of unnecessary technologies, prolongation of life in terminal situations, and disrespect for patients' autonomy ${ }^{(1-3)}$.

In this sense, some studies have demonstrated the need to sensitize nursing students to possible ethical problems arising during internships, and prepare them for challenges they may encounter throughout their professional career ${ }^{(4)}$. This way, the affective and cognitive dimensions of ethical thinking can be awakened in order that nursing students can have a keen sensitivity when facing ethically challenging situations in their future work environment ${ }^{(5-8)}$.

Moral sensitivity is considered an important skill for nursing, and necessary in moral decision making and management of ethical problems in different health care setting $\mathrm{s}^{(9)}$. The ability to be morally sensitive is needed in Intensive Care Unit contexts. These can be described as nursing care scenarios specialized in high complexity care, hence constantly demanding professionals with ethical profile, capable of reasoning critically and clinically, and who can associate the service between technology and assistance ${ }^{(10)}$.

Similarly, moral sensitivity can be considered as a personal, intuitive concept, or even a competence and an essential dimension in daily decision-making that arises from a search for moral meaning of the humans' doing $^{(4,11)}$. Moral sensitivity comprises the experiences and personal development of an individual and the experience of others. It is in a constant process of change and development throughout a professional's life ${ }^{(8)}$. The perspective of the moral sensitivity structure has been described by Lützén and Nordin with the focus on moral reasoning, a cognitive process involving objectivity and ability to apply principles when facing ethical problems ${ }^{(12)}$.

The components of moral sensitivity in nursing work can be understood in three specific domains: moral consciousness, benevolent motivation, and spontaneous moral perception ${ }^{(13)}$.

In moral consciousness, nurses need to be aware of their professional code of ethics and of eventual ethical conflicts occurring in the health care setting, and act according to their ethics code on those occasions. Benevolent motivation is the will to do what is known to be right and for the patient's good, by the other, to be altruistic. Finally, spontaneous moral perception is the nurse's ability to recognize ethical situations or problems that may arise, and at the same time be alert to feelings that may have an impact on patients ${ }^{(13)}$.

Nursing workers need to be prepared to face these problems, so they must develop the moral sensitivity that will influence them to act ethically in favor of patients, even in the face of conflicts/barriers to care $^{(14)}$. Likewise, nurses' ability to be morally sensitive requires their skills for identifying ethical and moral issues surrounding the care process, and for promoting patients' rights and interests.

However, in studies conducted in countries such as Iran, Thailand and South Korea, were found moderate levels of moral sensitivity in nurses. This is explained by the lack of professionals and constant challenges that differentiate theory from practice, and produce an adverse organizational atmosphere in everyday routine $\mathrm{e}^{(9,13,15)}$.
The present study is justified by the need to recognize how nurses have been proving morally sensitive to face ethical problems of the profession in intensive care units in the Brazilian context. This can provide important knowledge by enhancing the ethical dimension of nursing professionals. This need arises from the constant condition of ethical problems in professional performance, provides an important knowledge about the theme and enhances nursing professionals' ethical dimension.

In view of the above, the present study had the following research question: Which components of moral sensitivity are present among nurses in the face of ethical conflicts experienced in Intensive Care Units? To answer the research question, was established as objective of study: To identify the ethical problems from components of moral sensitivity among nurses of Intensive Care Units.

\section{OBJECTIVE}

To identify the ethical problems from components of Moral Sensitivity among Nurses of Intensive Care Units

\section{METHOD}

\section{Ethical aspects}

Ethical aspects were respected in accordance with the recommendations of Resolution 466/12 of the National Health Council. The article is part of the macro project entitled "Moral sensitivity in nursing: relations between patient advocacy and moral suffering", which was evaluated by the Local Research Ethics Committee (Portuguese acronym: FURG) and approved. In the study, participants were identified by the letter $E$ followed by a sequential number (E1 to E19) according to the order of interviews.

\section{Type of study}

This is a qualitative, exploratory-descriptive study. It was conducted in three Intensive Care Units of a philanthropic institution in the South of Brazil that is characterized as a Hospital Complex composed of three hospitals with a total of 541 beds, of which 27 are ICU beds.

ICU 1 is a general ICU with 11 beds, of which four are from the Intermediate ICU, intended for the care of patients from the Brazilian National Health System (Portuguese acronym: SUS) and, if necessary, for patients with health insurance. The focus of the service provided is mainly for diagnosis of polytrauma, stroke, hypertensive, diabetic, post-surgical, and cancer patients, among others. The nursing team has an administrative nurse with a workload of 40 hours/week; a care nurse with a workload of 36 hours/week working the morning and afternoon shifts; four care nurses working six hours/day distributed in morning, afternoon, night I and night II shifts; a nurse to perform work during breaks, and another nurse for holiday periods. In each shift, there are seven nursing technicians working.

ICU 2 is also a general ICU, with seven beds destined to patients with health insurance, who are affected by various pathologies. The nursing team has an administrative nurse with workload of 
Moral sensitivity components identified among nurses from Intensive Care Units Schallenberger CD, Tomaschewski-Barlem JG, Barlem ELD, Rocha LP, Dalmolin GL, Pereira LA

40 hours/week; four care nurses with a workload of 36 hours/week distributed in morning, afternoon, night I and night II shifts; and a nurse to perform the work during days off. In this unit, there are 16 nursing technicians distributed in morning, afternoon, night I and II shifts.

Finally, ICU 3 is a Postoperative Intensive Care Unit (PICU) with nine beds. It serves patients from the SUS and other health insurances with emphasis on the care of cardiovascular diagnoses. The nursing team has an administrative nurse with workload of 40 hours/week; four care nurses with a workload of 36 hours/week distributed in morning, afternoon, night I and night II shifts; a nurse to cover days off of daytime shifts; a nurse to cover absences (nights off) of night shifts; and a nurse to perform work during holiday periods. In the unit, there are also 24 nursing technicians distributed in morning, afternoon, night I and II shifts.

The study participants were 19 nurses working in the three intensive care units of the aforementioned institution. They were selected through non-probabilistic convenience sampling, according to presence at the study site and willingness to participate in the study at the time of data collection. Criteria for the selection of participants were the nurses of the ICUs selected for the study, who were working professionally in the unit for more than six months, and willing to answer the data collection instrument. Exclusion criteria were participants on vacation, on leave or leave of participating nurses.

\section{Data collection and organization}

The data collection period was August and September of 2016. It was held at participants' time and place of work in a specific room for ensuring their privacy. Semi-structured interviews were performed, and the questions were designed from previous reading of articles on the subject. For participants' characterization, the following issues were addressed: age, training time, highest academic qualification, among others. The open questions asked the following: What does it mean for you to be an ICU nurse? What are the ethical problems you experience in the ICU? What does moral sensitivity mean to you? Which characteristics do you believe are defining of a morally sensitive nurse to ethical problems? Interviews were recorded, had an average duration of 30 minutes, contained closed questions for the characterization of participants, and open questions focusing aspects related to nurses' actions and decision making for coping with ethical problems based on moral sensitivity.

\section{Data analysis}

The analysis of data obtained through interviews was performed from the discursive textual analysis that is a qualitative data analysis methodology. The aim of this methodology is to produce new understandings about discourses and phenomena through a self-organized process that includes a sequence of three steps: unitization, categorization and communication ${ }^{(16)}$.

In the unitization step, interviews were examined in details, and fragmented until reaching units of meaning, which constitute statements related to the studied phenomenon. In the categorization, were established relations between the units of meaning, so that categories were defined a priori based on the three domains of moral sensitivity: moral consciousness, benevolent motivation and spontaneous moral perception ${ }^{(13)}$. Communication was the last step of the analysis. It sought to demonstrate the understanding of the investigated phenomenon, which presents itself as the product of a new combination of the elements constructed along the previous steps ${ }^{(16)}$.

\section{RESULTS}

Regarding the characteristics of the 19 participants of the study, their age varied between 25 and 49 years and all were female. The time of professional training ranged from nine months to 22 years. The time of professional work ranged from six months to 20 years. Of the 19 nurses, ten had undergraduate degrees as highest academic qualification, eight had a specialization degree and one had a residency title.

In relation to the work units of the 19 nurses, eight worked in ICU 1, six worked in ICU 2 and eight worked in ICU 3. The prevailing weekly workload was 36 hours, and two nurses had a weekly workload of 40 hours. When questioned about holding meetings at the unit, 17 nurses responded there are periodic meetings every 15 days for training and problem solving in the unit where they work.

From data analysis, a priori were defined three categories: moral consciousness; benevolent motivation; spontaneous moral perception.

\section{Moral consciousness}

From the moral consciousness domain, were identified the following components of moral sensitivity among nurses in this category: nursing ethical education, clinical knowledge, dialogue, relationship with other health team members, and professional autonomy. These components help nurses with decision making in the face of ethical problems related to the defense of patients' rights and divergences in professional conduct according to the professional code of ethics.

Regarding ethical education, nurses reported this is a fundamental element to awaken nursing professionals about the responsibility to develop moral consciousness. This way, their actions can be focused on humanized care and the defense of patients' rights, such as their right to autonomy in making decisions related to their health care. Thus, nurses emphasized that ethical concepts involved in care and apprehended during professional training in the light of the code of ethics are important components to assist in the preservation of patients' rights, and in decision making in the face of ethical conflicts in the intensive care unit. These aspects are evident in the following reports:

We have a professional code of ethics and you know how far you can go. You know you have to respect the code of ethics. (E15)

One of the ethical problems is the difficulty of dealing with the rights and autonomy of patients and their relatives, bearing in mind that patients have the full right to participate concurrently in their care, as well as their relatives, in case the patient cannot answer for him/ herself [...]. It is necessary to put care into practice by optimizing the ethical concepts involved and preserving the patient's rights, prioritizing the practice of humanized care, seeking effective care. (E3) 
Moral sensitivity components identified among nurses from Intensive Care Units Schallenberger CD, Tomaschewski-Barlem JG, Barlem ELD, Rocha LP, Dalmolin GL, Pereira LA

Likewise, nurses expressed that relationships with other health team members can affect patient care when these are permeated by ethical problems, especially those related to the divergence of professional conduct. In these cases, dialogue is an important component for developing nurses' moral consciousness, since it favors nurses' autonomy, the exchange of experiences, and knowledge among professionals by helping to make morally correct decisions about patient care. This aspect can be observed in the subsequent statetments:

The issue of the multiprofessional team conduct is evident. Sometimes a medication, a procedure, a change of position could help in recovering the patient's health, and sometimes such care is lacking. I realize the need to get closer to the unit coordination, to have meetings in their presence, give voice to professionals, because an ICU environment demands more, patients are more critical, we miss the exchange of experience between colleagues. (E10)

I always reinforce to my team of nursing technicians about the importance of giving opinions, because sometimes this is the big problem of working in ICUs, the interpersonal issues. And there is the aspect of moral and ethics, because each one has an own view and a way of working that is different from mine, and I won't be able to change this. (E17)

\section{Benevolent motivation}

In this category, moral sensitivity is seen from components used by nurses in the exercise of benevolent motivation, which results from the desire to do what is believed to be right and the best for the patient. Among components of nurses' exercise of benevolent motivation are personal values, knowledge guided by clinical and critical reasoning, effective communication, teamwork, and patients' positive outcomes from the nursing care.

Personal values were evidenced as important guiding factors for decision making in the face of ethical problems throughout the care of patients hospitalized in intensive care units. Personal values support nurses' actions in the integral care to patients and defense of their rights, starting with a sense of responsibility for the life of the other, especially in cases of more vulnerable patients. This aspect is fully visible in the content of this interviewee:

I believe that morally sensitive nurses are nurses who care about the patient and are responsible in this sense, not only performing the work they are supposed to do, but they have an extra concern with the patient, with well-being, showing their willingness, and making others care about it too, they are able to visualize that about the patient, they should have another vision and not just the technical vision. (E18)

The same way, clinical knowledge was emphasized as an essential component for the development of benevolent motivation, since nurses have recognized that clinical and critical reasoning are key for patients' assessment, and for decision making based on patients' best benefits. By using knowledge as a strategy to help patients obtaining the necessary health care and ensuring the quality of care, nurses also reported they mobilize other members of the health team in pursuit of the same purposes by enhancing actions in defense of patients' benefits, as shown in the reports below:
For me, it is asking myself. Then comes the question, what if it was me? Is this right or is this not right? If you do not ask yourself, you do not sensitize yourself. And if I do not seek the knowledge, it will not affect me, and I won't know how to ask. (E13)

The ICU awakens the knowledge, the wanting to learn, to read, to understand, to seek the deeper comprehension of the different pathologies that appear, because there is always something new here, and for the patients' good it is necessary to study. (E7)

Knowing how to be resolutive implies having attitudes, knowing how to act without fear of doing it, if it will be for the patient's improvement in a situation and, if there are consequences, to assume them. The nurse must be the one who is there for the patient, fighting for the improvement. (E15)

Another evident aspect refers to the nature of the relationship with other health team members. This is an important component for nurses' exercise of benevolent motivation. This is especially noticeable when values and goals for patient care are shared, evidencing the importance of effective communication in multidisciplinary teams. This understanding is expressed in these discourses:

I believe nurses are the central axis in an ICU and have the responsibility of articulating with the multiprofessional team. They are responsible for coordinating with the doctor what would be the best for the patient. They need to motivate the team all the time in order to do a good job, and the key factor is communication. (E15)

I know what is right for the patient, although the mechanism for proper functioning is not always visible, I am only a key part and depend on the sequence of the service of co-workers. (E7)

Finally, the nurses reported that outcomes presented by patients as a result of nursing care enhance the actions in their benefit. This affirmation becomes a motivating factor to seek new knowledge and sensitize the other health team members in the search for quality of care, as shown in the speech below:

Always looking for knowledge and knowing that I can do something for the patient's life, for people and relatives is very gratifying. Even if there is no success in recovering health, but the satisfaction of having done what was possible, that I gave my best, provided care for the family at that moment, is a lot of gratitude. (E15)

\section{Spontaneous moral perception}

In this category, it was found that nurses are morally sensitive when exercising their capacity to recognize ethical problems in the work environment from the spontaneous moral perception. Thus, interviewed nurses have reported that leadership and knowledge are important components for helping in the identification and resolution of ethical problems experienced in the unit. Among these problems, were highlighted organizational conflicts, the lack of competence of health team members to act in intensive care units, and the divergence of conduct among professional categories. In addition, nurses demonstrated they were aware of such ethical problems, and the feelings generated by them can have a significant impact on patient care. Interviewees have reported: 
Conflicts stemming from non-agreed behaviors, from protocols not being followed between the on-call staff generatestress and discomfort, and in these cases, who ends up suffering are the patients, and at the same time, the work team themselves who end up in attrition. (E2)

To know how to interpret the existing ethical problems and work in a way that guarantees adequate and effective care for patients and their relatives. Nurses must have decision-making capacity based on ethical principles that involve care as a whole, and guarantee humanized and effective care for patients. (E3)

Clinical knowledge was again emphasized by nurses as an important component of moral sensitivity, since it helps with recognition and decision-making in the face of ethical problems. Therefore, from knowledge, nurses are able to question the conduct of other health team professionals that could affect patient care. Thus, an interviewed nurse said:

What is most evident are the relationships between professionals and the conducts one or another professional engages in, and ends up generating some problem/ethical dilemma that reflects on the patient. When listing the problems, I would say the conducts in the face of a guarded prognosis. (E18)

On the other hand, while recognizing clinical knowledge as an important component for identifying and making decisions regarding ethical problems, nurses reported the apparent lack of professional autonomy and dependence on medical conduct may potentiate such problems. This can often lead them to moral suffering. Thus, nurses have the capacity to recognize the ethical problems that cause suffering and can impact on patient care, according to the following reports:

Too much unnecessary investment and one sees suffering. For me it's one of the worst things I've ever seen in an ICU. The experience and knowledge one has are to see the investments are futile, we stay there, shall I do it or do it not, but the doctor has prescribed. (E15)

I feel doctors have some difficulty in following protocols, because the professional on-call determines something, then the other arrives and changes the conduct completely. For example: one says it is a comfort measure, the other says it is total investment, we never know, it changes every day, because every day is another professional on-call. When working with very serious patients with guarded prognoses such as comfort measures, as a nurse, I realize there is no comfort at all, it's far away from comfort. I end up feeling it, and it makes me suffer. (E9)

\section{DISCUSSION}

Ethical education, dialogue, relationships with other health team members, professional autonomy, knowledge, personal values, effective communication, leadership and patients' positive outcomes were perceived as important components of nurses' moral sensitivity. These specific aspects were identified from the following domains: moral consciousness, benevolent motivation and spontaneous moral perception. These findings corroborate the already evidenced results by identifying the moral sensitivity in nursing practice because of the frequent situations of facing ethical problems arising from situations related to the care of patients or their family, to the work organization, and relationship with other professionals ${ }^{(1)}$. Caregiving characterizes the professionals' action, and it must be beyond ethical problems that should not become barriers to nursing care, but help and stimulate professionals with the development of their decision making skills on a daily basis (OLIVEIRA, ROSA, 2015)(17).

Knowledge permeated the three domains of moral sensitivity explored in this study, which is in line with another study on the moral dimension of nursing care in intensive care units. That study showed nursing professionals seek a scientific basis and technical competence to support their actions, since knowledge is an indispensable attribute for moral action in the face of ethical problems. Thus, knowledge must be perceived as an essential tool for the training of nurses who are capable of handling routine conflicts $^{(18)}$.

Regarding the first category, moral consciousness, nurses seek to use the professional code of ethics in defense of patients rights in their work environments, and recognize the disrespect to patients' rights as an important ethical problem in intensive care units. Note that a study developed in southern Thailand with psychiatric nurses described that morally sensitive professionals are those who are aware of their code of ethics, of ethical events, their work and aware of their patients' feelings ${ }^{(13)}$. Thus, the professional code of ethics becomes an important instrument for nurses' support in the face of ethical challenges of the profession ${ }^{(19)}$.

Moral consciousness can be considered an interpretative process in which professionals recognize there is an ethical problem, and decision making is necessary from the professional code of conduct $^{(13)}$. Therefore, ethical education is a fundamental component in professional nurses' training in order that they become aware of the professional code of ethics, and develop knowledge and skills in decision making in the face of conflicts experienced in the work environment and the need for defense of patients' rights $^{(19-20)}$.

Furthermore, relationships with other health team members can impact on patient care when they are permeated by the divergence of professional conduct. A study on nurses' ethical performance in intensive care units stated that nurses should be aware of their actions, be able to reflect, and to dialogue with work teams and the reality surrounding them, thereby contributing to decision making about patient care ${ }^{(21)}$.

In this sense, it was also found that interviewed nurses prefer to use the dialogue with the health team for the establishment of conducts in relation to patient care, especially in the face of divergences of professional conduct. Similar results were found in studies in ICUs in the states of Rio Grande do Sul, Rio de Janeiro, and in the surgical ward in the state of Bahia (Brazil) about ethical decision making. In these studies, the dialogue appeared as a fundamental component in the relationship with other health team members, and it could minimize differences in professional conduct and promote quality care $^{(22-24)}$.

Regarding the domain of benevolent motivation, nurses showed personal values as important components of moral sensibility. This is defined as the will to do what is recognized as correct from personal motivations, as the nurse said "motivation is feeling sure to solve the problem by responding to the patients' needs"(13).

Thus, as already found in the literature, the nurses' internalization of values such as trust, harmony, friendship, dialogue, respect, 
Moral sensitivity components identified among nurses from Intensive Care Units Schallenberger CD, Tomaschewski-Barlem JG, Barlem ELD, Rocha LP, Dalmolin GL, Pereira LA

commitment, involvement, and responsibility seems imperative, since it is the nurses' role to make decisions regarding ethical problems. Moreover, they need to live with the team's satisfaction or dissatisfaction judgments because of the decision they had made for providing benefits to patients ${ }^{(17)}$. Benevolent motivation is potentialized in the sense that patients show linearity in care, and respond in a coherent way to their clinical picture. When actions are motivated by doing what one believes to be good or for patients' best interest, this is the manifestation of benevolence that can be measured from nurses' perceptions regarding moral sensitivity. This study evidenced the understanding of moral sensitivity from doing good ${ }^{(23)}$.

Regarding the domain of spontaneous moral perception, leadership and knowledge emerge as important factors for ethical problem management in the intensive care environment by interconnecting care with attention to the environment, such as in organizational conflicts, lack of competence and differences of professional conduct. In this sense, spontaneous moral perception represents the discernment of morally inadequate situations that can affect patient care, including moral reasoning, and the deliberation about what is the right thing to $\mathrm{do}^{(13)}$.

Thus, leadership is an indispensable element in the nursing work process. It will assist nurses in guiding the team, making decisions and coping with ethical problems arising in the work environment, especially when based on knowledge and technical skills ${ }^{(25-26)}$. Nurses shall be attentive to the team's human and intellectual development in order to strengthen them in decision making and the pursuit of common goals for sharing the results, minimizing conflicts and offering safe and quality care to patients ${ }^{(27)}$.

However, nurses'leadership may confront organizational conflicts such as the lack of protocols, materials and equipment that make the care process difficult. As already found in the literature, ethical problems arising from the absence of care protocols, lack of material resources and equipment can generate feelings of anguish and suffering in nurses. This is a result of their lack of clarity in relation to the protocol to follow, and for seeing the fragility and impossibility of performing activities with efficiency and quality ${ }^{(28-29)}$, especially considering the several inaccuracies arising in intensive care settings.

Likewise, the recovery of nurses' moral sensitivity so they recognize the ethical dimension of problems involved in the approach of patients hospitalized in intensive care units becomes a determinant. This rescue is essential for tackling ethical problems and for understanding patient care in its entirety ${ }^{(19)}$. Hence the need for actions with the aim to strengthen nurses' autonomy, which may minimize situations leading to experiences of ethical problems, especially moral suffering.

\section{Limitations of the study}

This study was conducted from a qualitative approach in a specific sample of nurses working in intensive care units of a hospital in the South of Brazil, which does not allow the generalization of their results. Still, the paucity of studies on moral sensitivity in Brazil makes it difficult to establish greater comparisons between the findings of the present study and the reality experienced by other nurses from different national contexts.

\section{Contributions to the Nursing area}

This study is relevant for the nursing area because studies of this kind are still in the initial phase at national level. Therefore, there are few studies investigating specifically the components of moral sensitivity of nurses and their repercussions for nursing care.

\section{FINAL CONSIDERATIONS}

The interviewed nurses were morally sensitive when recognizing disrespect for patients' rights, divergence of professional conduct, organizational conflicts and lack of professional competence as the main ethical problems experienced in the intensive care setting. To that end, ethical education, dialogue, relationship with other health team members, professional autonomy, knowledge, personal values, effective communication, leadership and patients positive outcomes were observed as important components of nurses' moral sensitivity, and could assist in the recognition and confrontation of the listed ethical problems.

Finally, the suggestion for other studies corroborating the deepening of knowledge about moral sensitivity in the Brazilian context seems relevant. Strategies for the development of moral sensitivity should also be explored and implemented in order to strengthen nurses' ethical actions and qualify both intensive care settings and other health care settings.

\section{REFERENCES}

1. Przenyczka RA, Kalinowski LC, Lacerda MR, Wall ML. Conflitos éticos da enfermagem na atenção primária à saúde e estratégias de enfrentamento. Ciênc Cuid Saúde [Internet]. 2011 [cited 2019 Jan 19];10(2): 330-7. Available from: http://dx.doi.org/10.4025/ cienccuidsaude.v10i2.12849

2. Barlem ELD, Lunardi VL, Tomaschewski JG, Lunardi GL, Filho WDL, Schwonke CRGB. Moral distress: challenges for an autonomous nursing professional practice. Rev Esc Enferm USP [Internet]. 2013 [cited 2019 Jan 19]; 47(2):506-10. Available from: http://dx.doi.org/10.1590/ S0080-62342013000200033

3. Teixeira C, Ribeiro O, Fonseca AM, Carvalho AS. Ethical decision making in intensive care units: a burnout risk factor? Results from a multicentre study conducted with physicians and nurses. J Med Ethics [Internet]. 2014 [cited 2019 Jan 19];40(2):97-103. Available from: http://dx.doi.org/10.1136/medethics-2012-100619

4. Tuvesson H, Lütze'n K. Demographic factors associated with moral sensitivity among nursing students. Nurs Ethics [Internet]. 2016 [cited 
Moral sensitivity components identified among nurses from Intensive Care Units Schallenberger CD, Tomaschewski-Barlem JG, Barlem ELD, Rocha LP, Dalmolin GL, Pereira LA

2019 Jan 19] 24(7):847-55. Available from: http://dx.doi.org/10.1177/0969733015626602

5. Yeom HA, Ahn SH, Kim SJ. Effects of ethics education on moral sensitivity of nursing students. Nurs Ethics [Internet]. 2016 [cited 2019 Jan 19];24(6):644-52. Available from: http://dx.doi.org/ 10.1177/0969733015622060

6. Lee HL, Huang SH, Huang CM. Evaluating the effect of three teaching strategies on student nurses' moral sensitivity. Nurs Ethics [Internet]. 2016 [cited 2019 Jan 19];24(6):732-43. Available from: http://dx.doi.org/10.1177/0969733015623095

7. Ahn SH, Yeom HA. Moral sensitivity and critical thinking disposition of nursing students in Korea. Int J Nurs Pract [Internet]. 2014 [cited 2019 Jan 19];20(1):482-9. Available from: http://dx.doi.org/ 10.1177/0969733015622060

8. Baykara ZG, Demir SG, Yaman S. The effect of ethics training on students recognizing ethical violations and developing moral sensitivity. Nurs Ethics [Internet]. 2015 [cited 2019 Jan 19];22(1):661-75. Available from: http://dx.doi.org/10.1177/0969733014542673

9. Borhani F, Abbaszadeh A, Mohamadi E, Ghasemi E, Hoseinabad-Farahani MJ. Moral sensitivity and moral distress in Iranian critical care nurses. Nurs Ethics [Internet]. 2017 [cited 2019 Jan 19];24(4):474-82. Available from: http://dx.doi.org/ 10.1177/0969733015604700

10. Rezende MLC, Macedo Costa KNF, Martins KP, Ferreira da Costa T. Comunicação entre a equipe de enfermagem e familiares de pacientes em unidade de terapia intensiva. Cult Cuid [Internet]. 2014 [cited 2019 Jan 19];39(18):84-92. Available from: https://rua.ua.es/dspace/ bitstream/10045/40070/1/Cultura_Cuidados_39_10.pdf

11. LützénK, Ewalds-kvist B. Moral distress and its interconnection with moral sensitivity and moral resilience: viewed from the philosophy of Viktor E. Frankl. J Bioeth Ing [Internet].2013 [cited 2019 Jan 19];10(3):317-24. Available from: http://dx.doi.org/ 10.1007/s11673-013-9469-0

12. Lútzen $\mathrm{K}$, Nordin, C. Benevolence, a central moral concept derived in a grounded theory study of nursing decision making in psychiatric settings. J Adv Nurs [Internet]. 1993 [cited 2019 Jan 19];18(7):1106-11. Available from: https://doi.org/10.1046/j.1365-2648.1993.18071106.x

13. Boonyamanee B, Suttharangsee W, Chaowalit A, Parker ME. Exploring moral sensitivity among Thai psychiatric nurses. Songklanagarind J Nurs [Internet]. 2014 [cited 2019 Jan 19];34(1):35-43. Available from: https://www.nur.psu.ac.th/journal/file/98file2733.pdf

14. Nora CRD, Zoboli ELCP, Vieira, M. Problemas éticos vivenciados por enfermeiros na atenção primária à saúde: revisão integrativa da literatura. Rev Gaúcha Enferm [Internet].2015 [cited 2019 Jan 19];36(1): 112-21. Available from: http://dx.doi. org/10.1590/1983-1447.2015.01.48809

15. Han SS, Kim J, Kim YS, Ahn S. Validation of a Korean version of the Moral Sensitivity Questionnaire. Nurs Ethics [Internet]. 2010 [cited 2019 Jan 19];17(1):99-105. Available from: http://dx.doi.org/ 10.1177/0969733009349993

16. Moraes R, Galiazzi MC. Análise Textual Discursiva. 2 ed rev. Ijuí (RS): Editora Unijuí; 2013. 224 p.

17. Oliveira MAN, Rosa DOS. Conflitos e dilemas éticos: vivências de enfermeiras no centro cirúrgico. Rev Baiana Enferm [Internet]. 2016 [cited 2019 Jan 19];30(1):344-55. Available from: http://dx.doi.org/10.18471/rbe.v1i1.14237

18. Couto Filho JC, Souza FS, da Silva SS, Yarid S, Sena EL. Ensino da bioética nos cursos de Enfermagem das universidades federais brasileiras. Rev Bioét [Internet]. 2013 [cited 2019 Jan 19];21(1):179-85. Available from: http://dx.doi.org/10.1590/S1983-80422013000100021

19. Silveira RS, Martins CR, Lunardi VL, Vargas MAO, Filho WDL, Avila LI. A dimensão moral do cuidado em terapia intensiva. Ciênc Cuid Saúde [Internet]. 2014 [cited 2019 Jan 19];13(2): 327-34. Available from: http://dx.doi.org/10.4025/cienccuidsaude.v13i2.19235

20. Barlem ELD. Formação profissional do enfermeiro e desafios éticos da profissão. Rev Rene [Internet]. 2014;15(5):731. Available from: http:// dx.doi.org/10.15253/21756783.2014000500001

21. Carvalho KK, Lunardi VL. Obstinação terapêutica como questão ética: enfermeiras de unidades de terapia intensiva. Rev Lat Am Enfermagem [Internet]. 2009 [cited 2019 Jan 19];17(3):21-7. Available from: http://www.scielo.br/pdf/rlae/v17n3/pt_05.pdf

22. Pavlish C, Ho A, Rounkle A. Health and human rights advocacy: perspectives from a Rwandan refugee camp. Nurs Ethics [Internet].2012 [cited 2019 Jan 19];19(4):538-49. Available from: http://dx.doi.org/10.1177/0969733011421627

23. Silva RC, Ferreira MA, Apostolodis T, Sauthier M. Nursing care practices in intensive care: an analysis according to ethics of responsibility. Esc Anna Nery [Internet]. 2016 [cited 2019 Jan 19];20(4):e20160095. Available from: http://dx.doi.org/10.5935/1414-8145.20160095

24. Camelo SHH. Competência profissional do enfermeiro para atuar em Unidades de Terapia Intensiva: uma revisão integrativa. Rev Lat Am Enfermagem [Internet]. 2012 [cited 2019 Jan 19]; 20(1):1-9. Available from: http://dx.doi.org/10.1590/S0104-11692012000100025

25. Silva VLS, Camelo SHH. A competência da liderança em enfermagem: conceitos, Atributos essenciais e o papel do enfermeiro líder. Rev Enferm UERJ [Internet]. 2013 [cited 2019 Jan 19] 21(4):533-9. Available from: https://www.e-publicacoes.uerj.br/index.php/ enfermagemuerj/article/view/10031

26. Moura GMSS, Inchauspe JAF, Dall'Agnol CM, Magalhães AMM, Hoffmeister LV. Expectativas da equipe de enfermagem em relação a liderança. Acta Paul Enferm [Internet]. 2013 [cited 2019 Jan 19]; 26(2):198-204. Available from: http://dx.doi.org/10.1590/ S0103-21002013000200015

27. Wong CA, Laschinger HK. Authentic leadership, performance, and job satisfaction: the mediating role of empowerment. J Adv Nurs [Internet]. 2013 [cited 2019 Jan 19];69(4):947-59. Available from: http://dx.doi.org/10.1111/j.1365-2648.2012.06089.x

28. Silva KCO, Quintana AM, Nietsche EA. Obstinação terapêutica em unidade de terapia intensiva: perspectiva de Médicos e enfermeiros. Esc Anna Nery. 2012;16(4): 697-703.

29. Rodrigues TDF. Fatores estressores para a equipe de enfermagem da unidade de terapia intensiva. REME Rev Min Enferm. 2012;16(3): 454. 